\title{
Yield Evaluation of Selected Clones Apomictic Iles-Iles (Amorphophallus muelleri Blume) on Second Growing Period
}

\author{
Evaluasi Hasil Klon Terpilih Apomiktik Iles-Iles \\ (Amorphophallus muelleri Blume) pada Masa Tumbuh Kedua
}

\author{
Adolf Pieter Lontoh $^{1}$, Edi Santosa ${ }^{1 *}$, Ani Kurniawati ${ }^{1}$, and Maryati Sari ${ }^{1}$ \\ ${ }^{1}$ Department of Agronomy and Horticulture, Faculty of Agriculture, Bogor Agricultural University \\ Jl. Meranti, Kampus IPB Darmaga, Bogor 16680, Indonesia
}

Received 9 December 2018/Accepted 8 April 2019

\begin{abstract}
Increasing corm production of iles-iles (Amorphophallus muelleri Blume) through genetic improvement is important for increasing farmers' income. However, the study on variety development is rarely reported. Here, yield evaluation of the second growing period was conducted at IPB Experimental Station Leuwikopo Farm, Bogor, Indonesia (-6.5647419, 106.7220331, 17.25z) from August 2017 to July 2018 in order to select candidate clone with high corm production. One-year-old corms of 21 F1 accessions were planted under 55\% shading net with four replications. The parent population was set as a control. Results showed that accessions exhibited variation in corm size. The parent population produced corm ranged 622.3-908.3 g in weight (on average 764.2 g). The pooled accessions produced corm 180.7-1527.5 g in weight, corm diameter 71.0-145.8 $\mathrm{mm}$, and corm height 46.6-87.6 mm. Nine accessions produced 5.91-99.88\% higher average corms weight than the parent, i.e., $B K B, B S, C F, C K, C R, D P G$, DPP, SBM, and SHJ. Based on $30 \%$ as the basis of corm weight improvement, we concluded that five accessions, i.e., $C K, C R, D P G, D P P$, and $S B M$ as prospective candidate clones. These accessions could be further evaluated in the third growing period to select best candidates of new variety of $\underline{A}$. muelleri.
\end{abstract}

Keywords: Agamosporous, Araceae, breeding strategy, new variety, productivity

\section{ABSTRAK}

Peningkatan produksi umbi iles-iles (Amorphophallus muelleri Blume) melalui perbaikan genetik penting untuk meningkatkan pendapatan petani. Namun demikian, studi terkait hal tersebut masih jarang dilakukan. Uji daya hasil (UDH) tahun kedua dari klon terpilih dilakukan di Stasiun Percobaan IPB Kebun Leuwikopo Bogor, Indonesia (-6.5647419, 106.7220331, 17.25z) pada Agustus 2017-Juli 2018 dalam rangka merakit varietas baru yang memiliki produksi lebih tinggi. Umbi umur setahun dari 21 aksesi F1 ditanam di bawah paranet 55\% dalam empat ulangan. Populasi tetua digunakan sebagai kontrol. Hasil menunjukkan adanya keragaman karakter umbi antar aksesi. Bobot umbi tetua berkisar 622.3-908.3 $\mathrm{g}$ (rata-rata $764.2 \mathrm{~g}$ ). Bobot umbi aksesi yang diuji berkisar 180.7-1527.5 g, diameter umbi berkisar 71.0-145.8 mm, dan tinggi umbi berkisar 46.6-87.6 mm. Sembilan aksesi memiliki bobot umbi rata-rata di atas tetuanya yakni BKB, BS, CF, $C K$, $C R, D P G, D P P, S B M$, dan SHJ. Bobot umbi kesembilan aksesi tersebut meningkat antara 5.91-99.88\% dari bobot rata-rata umbi tetuanya. Berdasarkan kriteria peningkatan bobot di atas 30\%, diperoleh 5 genotipe yakni CK, CR, DPG, DPP, dan SBM yang potensial sebagai calon varietas baru. Aksesi-aksesi tersebut perlu diuji lanjut pada periode tanam ke-3 sebelum ditetapkan sebagai varietas unggul baru iles-iles.

Kata kunci: Apomiktik, Araceae, produktivitas, strategi pemuliaan, varietas baru

\section{INTRODUCTION}

Popularity of growing tuberous iles-iles (Amorphophallus muelleri Blume, Araceae) to sustain rural farmer income through agroforestry system is increasing in Indonesia (Afifah et al., 2014). The corm is harvested

\footnotetext{
* Corresponding author. e-mail: edisang@gmail.com
}

for glucomannan production, a kind of low digestive and neutral carbohydrate that applicable to be used in food, beverage, pharmacy and other strategic industries (Haryani and Hargono, 2008; Sugiyama and Santosa, 2008; Keithley et al., 2013; Hananto et al., 2015; Dai et al., 2016; Yang et al., 2017). From $100 \mathrm{~g}$ dried chips, about 20-31 g pure glucomannan is obtained depend on extraction method (Dwiyono, 2014; Widjanarko and Suwasito, 2014). 
The plant usually grows under intercropping of perennial trees due to shading requirement (Sugiyama and Santosa, 2008; Zhao et al., 2010; Afifah et al., 2014). The cost of glucomannan production from $A$. muelleri is considered lower than other Amorphophallus species that requires a large amount of pesticides, fertilizers and replanting (Sugiyama and Santosa, 2008). The plant has multiple propagation systems using aerial bulbils and seed, supports continuous growing for years under the intercropping without replanting requirement (Zhang et al., 2010).

Beside high advantage in the cultivation system and ecological impacts, there is still a fundamental problem on growing $A$. muelleri, namely low crop productivity. Low productivity resulted in lower competitiveness as compared to other shade-loving crops (Rachmawati, 2008; Pranamulya et al., 2013; Supriadi and Pranowo, 2015). Under current practice, average annual corm production in the agroforestry is 6-12 ton $\mathrm{ha}^{-1}$ (PPKKP, 2013), while Dwiyono (2014) reported 4-6 ton ha ${ }^{-1}$. According to Rofik et al. (2017) fresh corm production ranges 1-4 ton $\mathrm{ha}^{-1}$ in east Java, depend on production system. Previously, Sugiyama and Santosa (2008) have estimated that production might reach 40 ton $\mathrm{ha}^{-1}$ annually. The low productivity is likely due to low corm size uniformity and long growing period. It is common that first harvest of the corm occurs at third year after planting from seeds or aerial bulbils (Zhang et al., 2010). Thus, genetic improvement with high corm uniformity, short growing period and high production is required. However, study on genetic improvement of $A$. muelleri is rarely reported.

Developing new variety in $A$. muelleri is rarely studied because it produces apomictic seed (agamosporous) that set without fertilization (Dani, 2008). It is known that apomict causes low genetic variation in many plants (Barcaccia and Albertini, 2013; Kandemir and Saygili, 2015). Nevertheless genetic variation in the $A$. muelleri has been noted (Poerba dan Martanti, 2008; Sedayu et al., 2010; Mekkerdchoo et al., 2011; Rosidiani et al., 2013; Nikmah et al., 2016; Santosa et al., 2018). Poerba and Martanti (2008) revealed that genetic diversity among populations ranges $0.02-0.36$, and Nikmah et al. (2016) noted that using $L E A F Y$ markers $A$. muelleri population exhibits different haplotype according to its origin.

According to Acquaah (2012) variety development in apomictic crop is simpler than that of conventional breeding in non-apomictic crops; see Savidan et al. (2001) and Hand and Koltunow (2014) for reviews. Therefore, present experiment could be first practical experience in variety development on how to improve apomict $A$. muelleri for higher yield. Here, we used 21 populations of selected elite accessions in order to develop high yielding clone. History and steps on crop improvement strategy of $A$. muelleri is also discussed.

\section{MATERIALS AND METHODS}

Corm evaluation was conducted from August 2017July 2018 at Leuwikopo Experimental Farm (245 m above sea level) of Bogor Agricultural University, Bogor, Indonesia (-6.5647419, 106.7220331, 17.25z).

Original propagule of $A$. muelleri was introduced to Bogor Agriculture University from Nganjuk District, East Java in early 2000s. Before determining the improvement method, crop life cycle was observed from separate experiment. The observation was made in 2006-2017 during populations establishment in both farmer fields (about one hectare), in Cikabayan (about $1000 \mathrm{~m}^{2}$ ) and Leuwikopo Experimental Farm Bogor Agriculture University (about $3000 \mathrm{~m}^{2}$ ). In brief, plant growth and development from seeds and bulbils were evaluated.

Twenty one accessions of one-year-old corms were evaluated in present experiment, i.e., BD, BKR, LSP, SBS, SC, SMM, STL, STS, SR, SB, SGH, SGBKK, BKB, BS, CF, CK, CR, DPG, DPP, SBM, and SHJ genotypes. Selected genotypes were originally from the farmer field that planted approximately 40,000 individuals (Figure 1). The parent population was maintained under agroforestry system under 15-year-old teak plantation in the farmer property near university farm in Bogor. Light intensity under the teak plantation was around $60-70 \%$ of full sunshine. Here, original population was determined as parent population (P0).

As clonal propagated-species, genotype improvement in A. muelleri followed Acquaah (2012). Establishment of genetic material for present experiment was from 20142017; the step was presented in Figure 2. About 500 corms were collected among those individuals that produced corms larger than $2 \mathrm{~kg}$ and noted as $\mathrm{P} 1$. The corms of $\mathrm{P} 1$ population was then planted in Leuwikopo (Y-2; 2014-2015) under artificial shading net 55\% and supplemented with sprinkler irrigation; the P1 plants that exhibited superior growth, and high corm weight were tagged, grouped and noted as P2. In 2015-2016 (Y-1), P2 corms were enforced with gibberellin (1000-2000 ppm) to stimulate flowering and seed production. Selection was made in $\mathrm{P} 2$ population based on unique characters of inflorescence and infructescence. Unique characters included inflorescence with extra-large size, unusual color and shape of spate, cone, peduncle color,

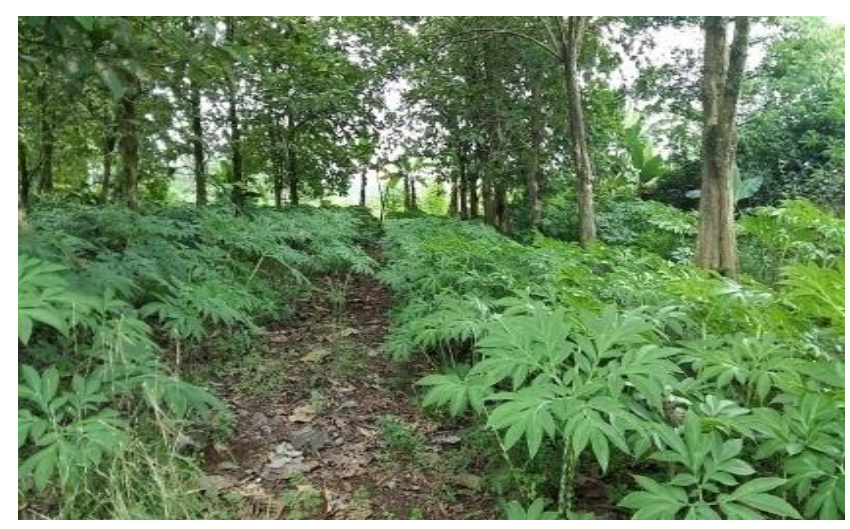

Figure 1. Population of Amorphophallus muelleri under teak plantation in Bogor using agroforestry system. Land property belongs to Dr Fred Rumawas, and used for research by his permission 

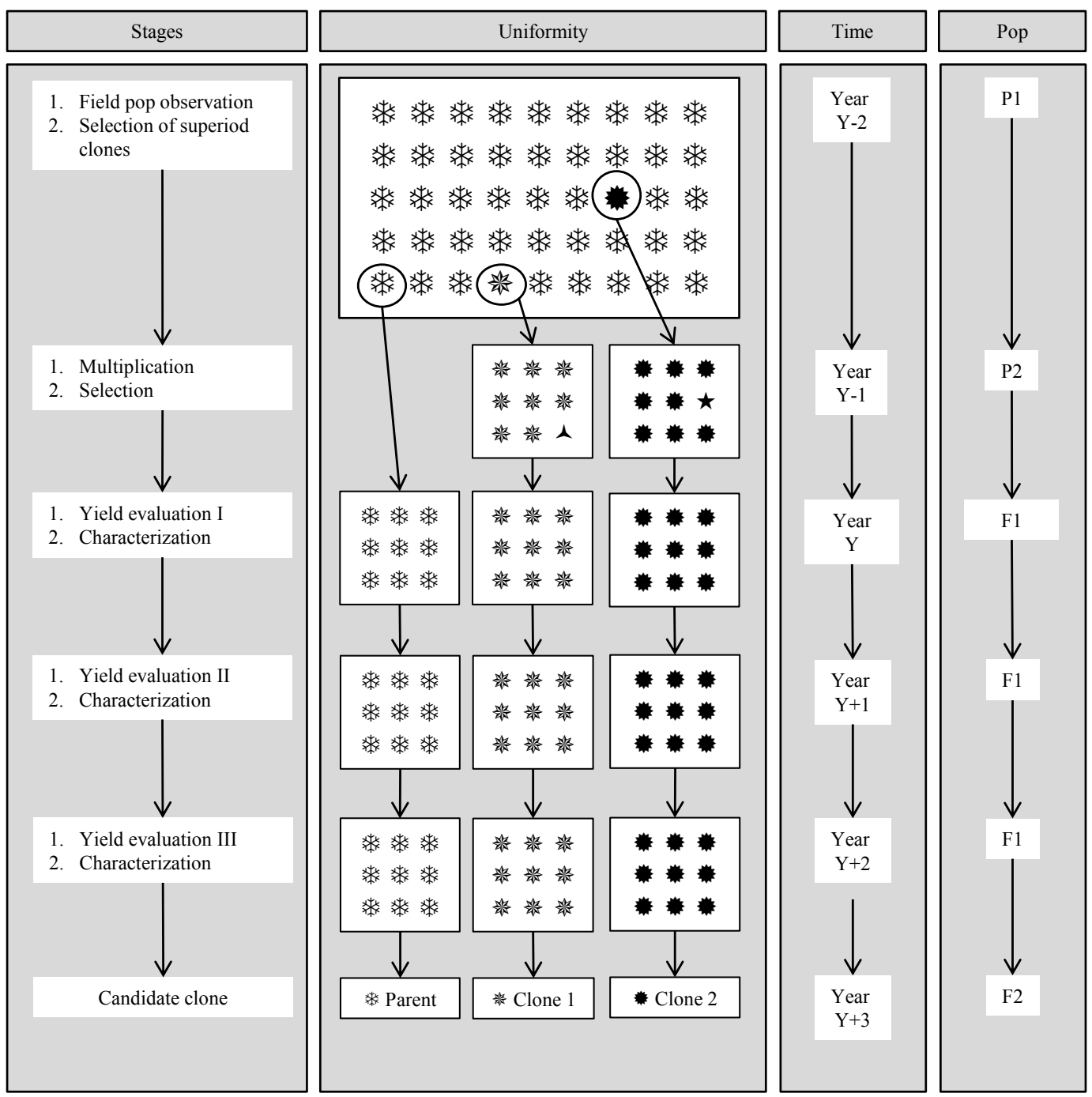

Figure 2. Five stages of new clone development on apomicts A. muelleri after modification from Acquaah (2012). Stage of present study is at Year $\mathrm{Y}+1$. P-parent, $\mathrm{F}$ progeny

fruit shape, and other morphologies. From P2 population, we selected 21 accessions (F1) and harvested the seeds. Each progeny was from single corm. The seeds of each accession were planted for first yield evaluation in 2016-2017, and small corms were harvested at dry season of 2017. The harvested corm was noted as F1-1. The propagule of parent population evaluation was descended from bulbils.

In the evaluation of 21 accessions F1-1, each genotype was planted in four replications under 55\% shading net; and arranged in randomized block design. Due to propagule limitation of each accessions, number of plant within replication differed, it ranged 20-87 plants.

Land was prepared using complete plowing method. Initially, the land was plowed using tractor and then harrowed twice. F1-1 seed corms (3-12 $\mathrm{cm}$ in diameter) were planted inside furrow seized $20 \times 100 \times 600 \mathrm{~cm}$ (Depth $\mathrm{x}$ Width $\mathrm{x}$ Length) using triangle planting distance of $50 \mathrm{x}$ $50 \times 50 \mathrm{~cm}$.

At planting in August 2017, $1 \mathrm{~kg} \mathrm{~m}^{-1}$ of cow manure was applied inside the furrow and then the manure was covered with some mount of soil. At 10 weeks after planting
(WAP), half of N:P:K fertilizers at rate of 100:60:80 ha-1 was applied. The other half of NPK fertilizers was applied at 20 WAP. Nitrogen was originally from compound NPK fertilizers (NPK Mutiara, 15\% NPK). Additional nitrogen was obtained from urea $(46 \% \mathrm{~N})$, potassium from $\mathrm{KCl}(60 \%$ $\left.\mathrm{K}_{2} \mathrm{O}\right)$ and phosphorus from SP-36 $\left(36 \% \mathrm{P}_{2} \mathrm{O}_{5}\right)$. Weeds were uprooted manually. Watering was provided from rainfall without any supplement irrigation.

Harvesting F1-2 corm was conducted at 35-40 WAP (May-July 2018) at the time plant entered dormancy as indicated by complete leaf senescence. Corm characters included fresh weight, diameter and height, corm shape and healthiness were evaluated. Marketable size was determined from the fresh corm weight $\geq 1,000 \mathrm{~g}$, free from disease infection and shaped globose or depressed-globose.

Corm weight data of F1-2 was evaluated using ANOVA. Further evaluation was conducted using LSD at level of 5\% when $\mathrm{F}$ test exhibited significant different. Here, we hypothesis that $A$. muelleri is obligate apomictic thus progeny is $100 \%$ maternal. In this context, estimates for selection advanced and expected genetic advance were 
based on broad sense heritability $\left(\mathrm{h}^{2}{ }_{\mathrm{bs}}\right)$, see Mulyadiana et al. (2019) and Syukur et al. (2015) with slight modification. Briefly, selection advanced $(\mathrm{SA})=\bar{x} F_{c}-\bar{x} F_{p}$; where $\bar{x} F n=$ mean current population and $F c=$ mean parent population. Expected genetic advance $(\mathrm{G})=(i)(\sigma p)\left(\mathrm{h}^{2}{ }_{\mathrm{bs}}\right)$; where $(i)=$ selection intensity, $(\sigma p)=$ standard deviation, $\left(\mathrm{h}^{2}{ }_{\mathrm{bs}}\right)=$ broad sense heritability. Broad sense heritability was estimated from equation: $\left(\mathrm{h}^{2}{ }_{\mathrm{bs}}\right)=\left[\left(\sigma^{2} F_{c}-\left(\sigma^{2} F_{p}+\sigma^{2} F_{c}\right) / 2\right] / \sigma^{2} F_{c}\right.$; where $\sigma^{2} F_{c}$ $=$ variance of current population, $\sigma^{2} F_{p}=$ variance of parent population. Selection proportion (SP) was estimated from average of two selection steps, i.e., $(\mathrm{SP})=\{[(500 / 40000)+($ $21 / 500)] \times 100 \%\} / 2=\{[0.0125+0.042] \times 100 \%\} / 2=2.725 \%$ of the population; selection intensity $(i)$ based on reference table was determined as 2.06 .

\section{RESULTS AND DISCUSSION}

\section{Crop Life Cycle}

In the field growing period followed the climatic season. The seed, bulbils and seed corm actively produced leaf(s) during rainy season and went dormancy during dry season. The plant exhibited perennials life cycle. In the first three year, it predominantly produced leaf and then an inflorescence emerged in rainy season at fourth year (Figure 3). All inflorescences produced berries and seeds without any leaf, called as solitary inflorescence. The berries matured in subsequent dry season.

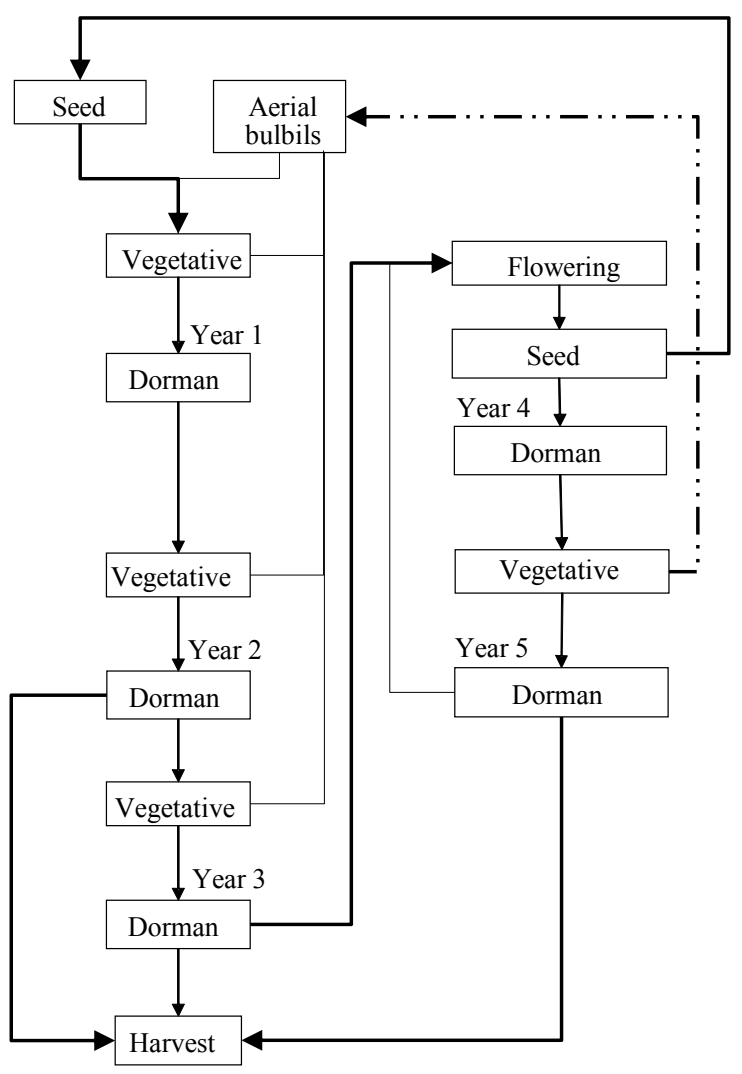

Figure 3. Life cycle of $A$. muelleri including seeds and aerial bulbils sources of an existing population
Corm after flowering continued to produce single large leaf in the next rainy season. After leaf dormancy, the corm produced another larger inflorescence than previous one. It meant that after first flowering, subsequent flowering time occurred at every two years (biannual cycle) as shown in Figure 3. This flowering cycle has been described (Santosa et al., 2016a). In our experiment, removing inflorescence stimulated vegetative growth; however, the corm produced another inflorescence in the next growing season.

The largest corm size was harvested after leaf senescence at the end of third year or at dormant state after vegetative (Figure 3). The harvest directly from flowering corm was not recommended, because the corm had abnormal shape. Also, according to Sugiyama and Santosa (2008), corms after flowering has low dry mass and glucomannan content. It is worthy to note that under Bogor climate, dry season commonly occurs May to August while rainy season occurs on September to April. Unlike vegetative growth that was completely suspended during dry season, the generative growth e.g. fruit maturation continued during dry season until fruiting complete at the end of the dry season. Nevertheless, in some years with extended rainy season (also meaning short dry season) such as in 2016 some plants with leaves postponed dormancy until May/June or produced leaves earlier in August than usually in September/October. Thus, it is important to consider climatic situation with distinct dry season to obtain optimum dry mass content in the $A$. muelleri production.

\section{Yield Performance}

Accessions of F1-2 population exhibited variation in corm weight, diameter and height (Table 1). The corm size variation was higher in the progeny than the parent population. Parent population produced corm 622.3-908.3 g (average $764.2 \mathrm{~g}$ ), while average progeny population produced 11.0-2207.0 (average $760.0 \mathrm{~g}$ ). Minimum corm weight across progeny accessions was $11.0-891.0 \mathrm{~g}$ and maximum 440.7-2207.0 g (average 180.7-1527.5 g). Minimum corm diameter was 23.0-117.9 mm and maximum 107.2-263.8 $\mathrm{mm}$ (average 71.0-145.8 $\mathrm{mm}$ ). The minimum corm height ranged $21.6-77.5 \mathrm{~mm}$ and the maximum ranged 64.4-107.9 $\mathrm{mm}$ (average 46.6-87.6 mm).

Estimate values on selection advanced and expected genetic advanced were negative (Table 1). These negative values could be due to high incident of extreme small corm size in the some accession. After correction by omitting the extra small corms $(<50 \mathrm{~g})$, selection advanced estimate for corm weight, corm diameter and corm height were 100.81 $\mathrm{g}, 11.08 \mathrm{~mm}$ and $4.98 \mathrm{~mm}$, respectively. It indicated that all 21 accession collected need further selection.

From 21 accessions 12 accessions had average corm weight below its parent, i.e., BD, BKR, LSP, SBS, SC, SMM, STL, STS, SR, SB, SGH, and SGBKK; and 9 other accessions had above the parent, i.e., BKB, BS, CF, CK, CR, DPG, DPP, SBM, and SHJ. Across nine accessions, corm weight increased by about 5.91-99.88\% from the parent. Based on $30 \%$ increasing rate in corm weight, five 
Table 1. Genetic parameters of progeny population of $A$. muelleri from second growing period

\begin{tabular}{lccc}
\hline Genetic parameters & Fresh corm weight $(\mathrm{g})$ & Corm diameter $(\mathrm{mm})$ & \multicolumn{1}{c}{ Corm height $(\mathrm{mm})$} \\
\hline Selection advanced $(\mathrm{SA})$ & -110.320 & -3.000 & -0.770 \\
Broad sense heritability $\left(\mathrm{h}^{2}{ }_{\mathrm{bs}}\right)$ & -0.084 & -0.013 & -0.006 \\
Expected genetic advanced $(\mathrm{G})$ & -80.466 & -0.882 & -0.216 \\
\hline
\end{tabular}

accessions, i.e., CK, CR, DPG, DPP, and SBM gained $99.88 \%, 48.60 \%, 46.38 \%, 34.90 \%$ and $31.02 \%$ higher from its parents, respectively (Table 2). Present finding showed that corm size in $A$. muelleri was likely affected by accession name; and it is not only determined by plant age as stated by Budiman and Arisoesilaningsih (2012). According to Poerba and Martanti (2008) A. muelleri in Saradan population exhibits high genetic diversity. The district name similar to the area of the original source of the propagule in present study; we speculate the presence of mutation in A. muelleri propagule as shown in present study.
The average minimum corm weight across accessions was mostly smaller than that of the parent, with exceptions DPG and CK genotypes were $43.18 \%$ and $22.45 \%$ larger than its parent, respectively (Table 2). The superiority of DPG and CK genotypes to the parent also was noted in diameter and height. Further selection based on corm weight is needed, because corm diameter and height according to Santosa et al. (2004) is affected by culture practice; deep planting causes corm elongation. Thus, corm weight seems as better estimator to distinguish A. muelleri accession. This case was observed in CR genotype, where average

Table 2. Relative percentage of corm weight, corm diameter, and height of twenty-one $A$. muelleri accessions to its parent from second growing period

\begin{tabular}{|c|c|c|c|c|c|c|c|c|c|}
\hline \multirow{2}{*}{$\begin{array}{l}\text { Accession } \\
\text { Code }\end{array}$} & \multicolumn{3}{|c|}{ Corm weight $(\%)^{z}$} & \multicolumn{3}{|c|}{ Corm diameter $(\%)$} & \multicolumn{3}{|c|}{ Corm height (\%) } \\
\hline & Min & Max & Avg & Min & Max & Avg & Min & Max & Avg \\
\hline $\mathrm{BD}$ & $-71.40 b c$ & $24.85 b c$ & $-16.65 b$ & $-45.23 b c$ & $14.92 b$ & $-4.23 b$ & $-21.52 \mathrm{ab}$ & $24.01 \mathrm{ab}$ & $3.12 \mathrm{ab}$ \\
\hline $\mathrm{BKB}$ & $-47.72 b c$ & $78.25 \mathrm{ab}$ & $5.91 \mathrm{ab}$ & $-12.73 a b$ & $26.11 b$ & 7.61ab & $-2.79 a$ & $41.14 \mathrm{a}$ & $17.04 \mathrm{ab}$ \\
\hline BKR & $-84.49 c$ & $-11.81 b c$ & $-43.04 b c$ & $-40.46 b$ & $0.42 b$ & $-14.70 b$ & $-34.90 a b$ & $6.51 b c$ & $-10.90 b c$ \\
\hline $\mathrm{BS}$ & $-56.43 b c$ & $83.11 \mathrm{ab}$ & $27.17 \mathrm{ab}$ & $-15.36 a b$ & $34.41 \mathrm{ab}$ & $15.33 \mathrm{ab}$ & $-12.41 \mathrm{a}$ & $38.86 \mathrm{a}$ & $19.53 \mathrm{ab}$ \\
\hline $\mathrm{CF}$ & $-50.15 b c$ & $76.11 \mathrm{ab}$ & $16.55 \mathrm{ab}$ & $-13.51 \mathrm{ab}$ & $24.44 b$ & $10.75 \mathrm{ab}$ & $-12.97 \mathrm{a}$ & $30.47 \mathrm{ab}$ & $13.90 \mathrm{ab}$ \\
\hline $\mathrm{CK}$ & $22.45 b c$ & $142.98 \mathrm{a}$ & $99.88 \mathrm{a}$ & $2.40 \mathrm{ab}$ & $38.54 \mathrm{ab}$ & $26.80 \mathrm{a}$ & $11.89 \mathrm{a}$ & $29.70 \mathrm{ab}$ & $23.69 \mathrm{ab}$ \\
\hline $\mathrm{CR}$ & $-21.25 b$ & $101.23 \mathrm{ab}$ & $48.60 \mathrm{ab}$ & $2.85 \mathrm{ab}$ & $30.91 \mathrm{ab}$ & $21.62 \mathrm{a}$ & $5.95 \mathrm{ab}$ & $42.77 \mathrm{a}$ & $27.55 \mathrm{a}$ \\
\hline DPG & $43.18 \mathrm{a}$ & $51.05 \mathrm{ab}$ & $46.38 \mathrm{ab}$ & $13.83 \mathrm{a}$ & $20.64 b$ & $18.74 \mathrm{ab}$ & $25.99 a$ & $24.03 \mathrm{ab}$ & $25.97 \mathrm{a}$ \\
\hline DPP & $-38.05 b$ & 74.94ab & $34.90 \mathrm{ab}$ & $-8.45 \mathrm{ab}$ & $23.70 \mathrm{~b}$ & $15.56 \mathrm{ab}$ & $1.94 \mathrm{ab}$ & $24.13 \mathrm{ab}$ & $17.00 \mathrm{ab}$ \\
\hline SBM & $-38.92 b$ & $99.30 \mathrm{ab}$ & $31.02 b$ & $-13.86 a b$ & $29.56 \mathrm{ab}$ & $12.39 \mathrm{ab}$ & $-4.63 a$ & $35.54 \mathrm{ab}$ & $17.62 \mathrm{ab}$ \\
\hline LSP & $-70.89 b c$ & $32.25 b$ & $-13.40 b$ & $-28.29 a b$ & $10.95 b$ & $-2.84 b$ & $-24.81 \mathrm{ab}$ & $12.22 b$ & $-0.66 b$ \\
\hline SBS & $-98.23 c$ & $-36.47 c$ & $-71.42 \mathrm{c}$ & $-77.84 c$ & $-6.05 b$ & $-34.85 c$ & $-59.24 b$ & $-8.83 c$ & $-31.36 c$ \\
\hline $\mathrm{SC}$ & $-68.10 b c$ & $21.09 \mathrm{bc}$ & $-25.11 b$ & $-31.28 b$ & $9.67 b$ & $-7.97 b$ & $-24.36 a b$ & $10.10 \mathrm{~b}$ & $-7.76 b$ \\
\hline SHJ & $-40.46 b$ & $76.54 \mathrm{ab}$ & $28.58 \mathrm{ab}$ & $-9.06 a b$ & $17.80 \mathrm{~b}$ & $9.04 \mathrm{ab}$ & $8.16 \mathrm{a}$ & $23.18 \mathrm{ab}$ & $18.81 \mathrm{ab}$ \\
\hline SMM & $-78.82 b c$ & $18.11 b c$ & $-24.15 b$ & $-38.94 b$ & $10.67 b$ & $-6.51 b$ & $-24.34 a b$ & $15.41 b$ & $-1.93 b$ \\
\hline STL & $-75.37 b c$ & $40.34 b$ & $-8.70 b$ & $-30.52 b c$ & $13.22 b$ & $-1.89 b$ & $-20.39 a$ & $24.47 \mathrm{ab}$ & $2.33 b$ \\
\hline STS & $-97.48 c$ & $-51.48 c$ & $-76.35 c$ & $-72.90 c$ & $-15.27 b$ & $-38.22 \mathrm{c}$ & $-64.83 b$ & $-14.86 c$ & $-32.24 c$ \\
\hline SR & $-77.72 b c$ & $31.93 b$ & $-26.90 b$ & $-35.44 b$ & $15.22 b$ & $-6.91 b$ & $-26.69 a b$ & $20.01 \mathrm{ab}$ & $-2.25 b$ \\
\hline SB & $-83.61 b c$ & $92.47 \mathrm{ab}$ & $-11.24 b$ & $-40.88 b$ & $108.50 \mathrm{a}$ & $4.03 \mathrm{ab}$ & $-41.87 a b$ & $41.87 \mathrm{a}$ & $3.91 b$ \\
\hline $\mathrm{SGH}$ & $-83.33 b c$ & $53.42 \mathrm{ab}$ & $-13.38 b$ & $-33.88 b$ & $20.55 b$ & $1.26 \mathrm{ab}$ & $-33.74 a b$ & $23.68 \mathrm{ab}$ & $2.21 \mathrm{~b}$ \\
\hline SGBKK & $-86.94 b c$ & $34.40 \mathrm{~b}$ & $-24.36 b$ & $-43.29 b$ & $20.55 b$ & $-3.12 b$ & $-52.44 b$ & $28.31 \mathrm{ab}$ & $-6.12 b$ \\
\hline Parent $^{\mathrm{y}}$ & 622.30 & 908.30 & 764.20 & 103.60 & 126.50 & 115.00 & 61.50 & 75.60 & 68.70 \\
\hline
\end{tabular}

Note: ${ }^{\mathrm{z} N e g a t i v e}$ value indicates smaller than the parent. ${ }^{\mathrm{y}}$ Corm weight in gram, diameter and height of corm in mm. Values in a column followed by different alphabeth is significantly different after LSD test at $95 \%$ level of confident. Statistical analysis after data transformation using $\log (\mathrm{x}+200)$ 
diameter and height of corm were larger but its corm weight was $21.25 \%$ smaller than the parent. Nevertheless, it needs further study because the shape of corm is commonly used to distinguish tuberous genotype like in Dioscorea sp. (Islam et al., 2011; Chinedu, 2017).

In term of production potential, assuming the planting density in the production field was 4 plant $\mathrm{m}^{-2}$, five accessions had production potential about 40 ton $\mathrm{ha}^{-1}$ of freshtuber or larger, i.e., CK, CR, DPG, DPP and SBM (Figure 4). Dashed line is about 40 ton ha $^{-1}$ based on potential yield proposed by Sugiyama and Santosa (2008). Interestingly, CK accession had potential yield 61.1 ton $\mathrm{ha}^{-1}$, the highest among accessions.

Superiority of the parent across some tested genotypes is presumably due to differences on the initial propagule size at planting, as previously been observed by Sugiyama and Santosa (2008). In A. paeoniifolius, Santosa and Sugiyama (2007) noted that larger seed corms produced larger daughter corms. In present research, propagule of the parent was derived from bulbils (10-20 g) while progeny was from seed. The different propagule source could be another factor contributed to negative values of genetic properties of the population. In the future, it is important to evaluate similar propagule such as using aerial bulbils from both the parent and the progeny.

\section{Marketable Size}

Accessions exhibited different number on marketable sized-corm (Figure 5). The parent produced 32\% corm as marketable size. Nine accessions, i.e., BKB, BS, CF, CK, CR, DPG, DPP, SBM and SHJ produced higher percentage of marketable corm weight than that of the parent; the highest percentage was from $\mathrm{CK}$ and $\mathrm{CR}$ accessions with percentage $66.67 \%$ and $66.98 \%$, respectively. Judgment from such criteria, both $\mathrm{CK}$ and $\mathrm{CR}$ accessions could be further evaluated as the most prospective clones of $A$. muelleri.

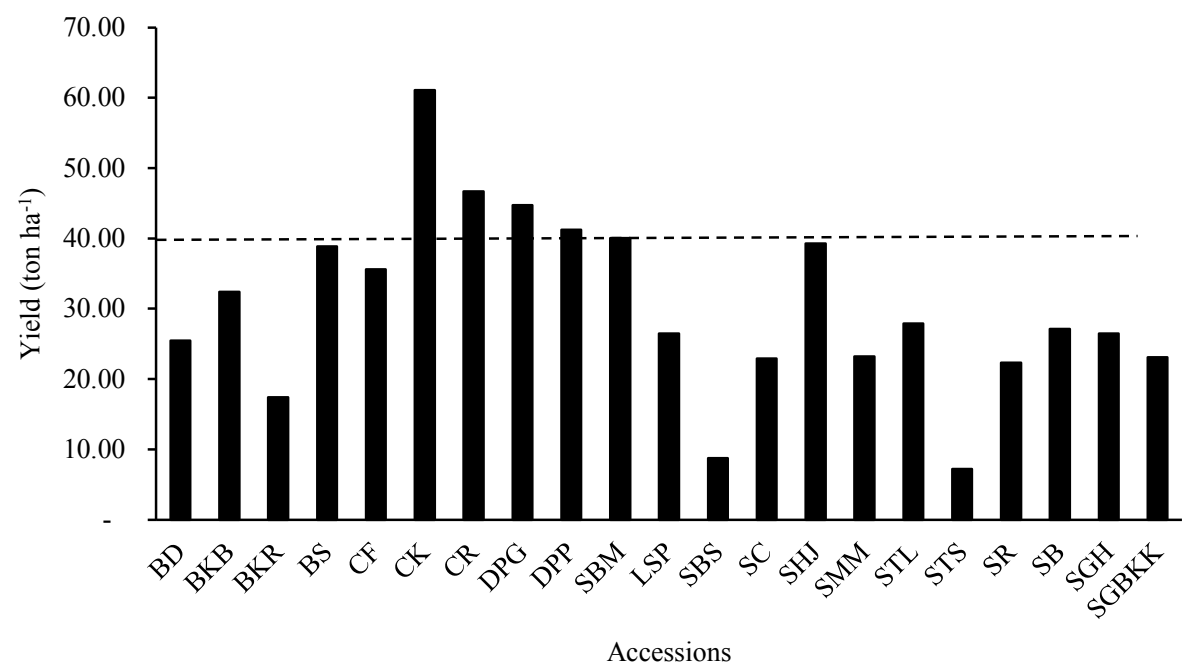

Figure 4. Potential yield of fresh corm production among A. muelleri accessions

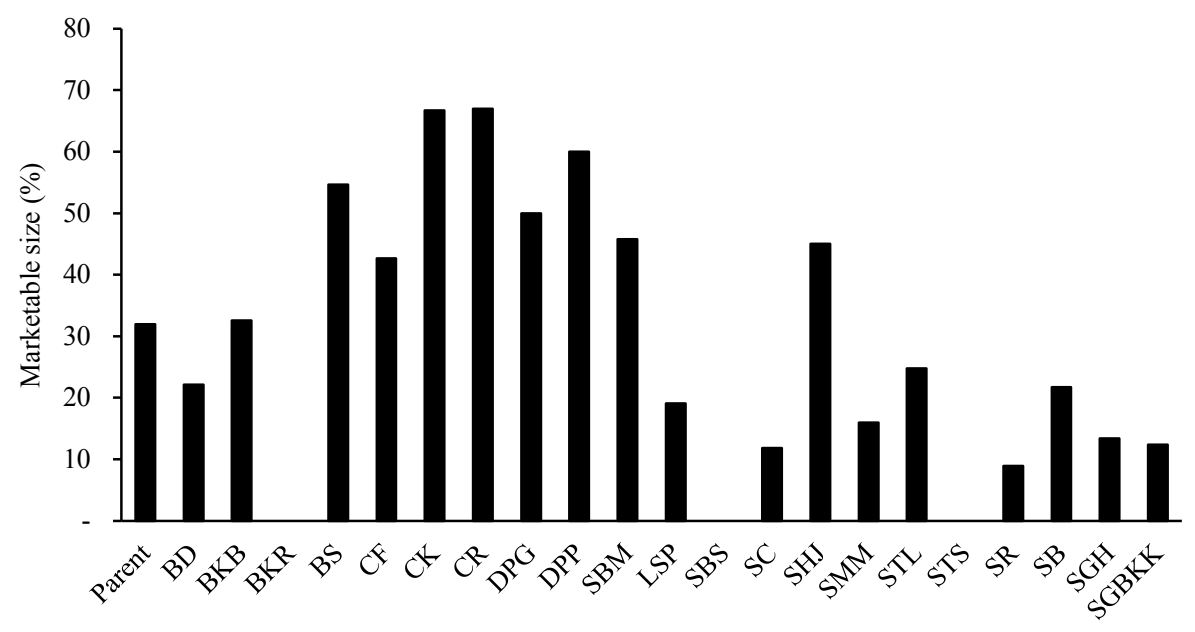

Accessions

Figure 5. Percentage of marketable corms from 21 accessions of $A$. muelleri from second growing period evaluation. No value of BKR, SBS and STS accessions indicated those all accessions produced fresh corms smaller than $1,000 \mathrm{~g}$ 
Indeed, Sugiyama and Santosa (2008) have noted that marketable size is 3-year-old corms with $>1500 \mathrm{~g}$ in weight. In A. paeoniifolius Santosa and Sugiyama (2007) concluded that seed corm size is known directly correlate with the corm weight at harvest, i.e., larger sized-seed corms absolutely produce larger sized-daughter corms at harvest. Here, we evaluated second growing period, and the corms will be used as seed corms for the third growing period. In farmer field, according to Sugiyama and Santosa (2008) harvests corm 500-600 $\mathrm{g}$ in weight is common from second growing period. In present experiment, corms weight was $1167-1527 \mathrm{~g}$ on average or $133-155 \%$ higher than that usually harvested by farmer. It means that early harvesting in $A$. muelleri is possible by obtaining fast growing clones such as using CK and CR accessions.
We noted that three accessions produced corms without marketable size in present experiment, i.e., BKR, SBS, and STS (Figure 6). The SBS and STS accessions mostly produced corms smaller than $250 \mathrm{~g}$ at rate 61 and $71 \%$, respectively, while BKR accessions mostly produced corm smaller than $500 \mathrm{~g}$. The cause of light weight corm production in these three accessions need further study whether it was caused by genetic properties or by other factors. In $A$. muelleri, application of $\mathrm{N}$ and $\mathrm{K}$ fertilizers significantly increase corm weight (Sumarwoto and Widodo, 2008; Santosa et al., 2016b). According to Santosa et al. (2016b) application $100 \mathrm{~kg} \mathrm{~N}, 60 \mathrm{~kg} \mathrm{P}_{2} \mathrm{O}_{5}$ and $80 \mathrm{~kg} \mathrm{~K}_{2} \mathrm{O}$ for one hectare increases corm production by $63 \%$ than without fertilizer application.

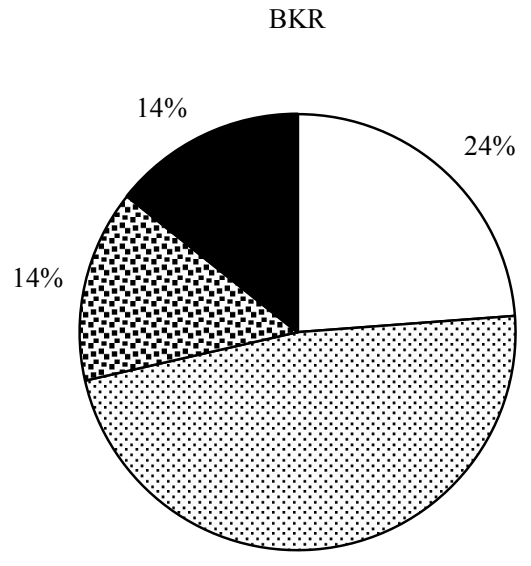

$48 \%$
SBS

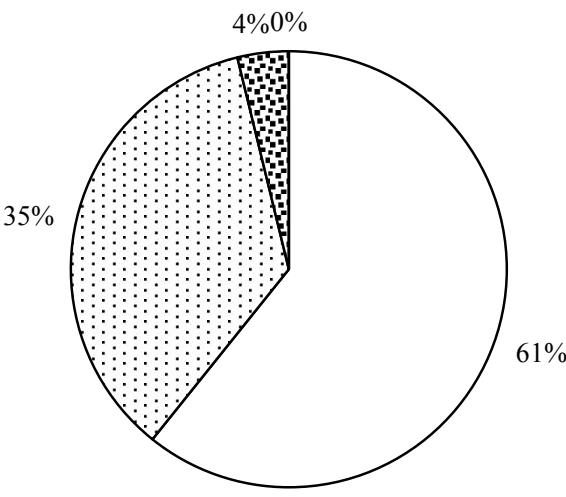

$\square<250 \mathrm{~g} \quad \square 251-500 \mathrm{~g} \quad \square 501-750 \mathrm{~g} \quad \mathbf{\square}>750 \mathrm{~g}$
Shadow express different corm weight

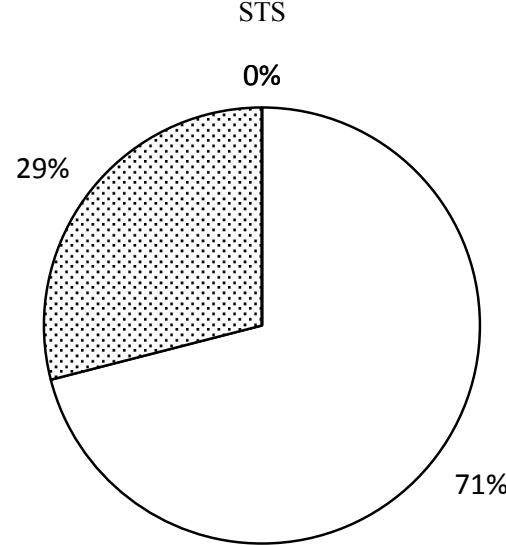

$71 \%$

Figure 6. Corm weight distribution of BKR, SBS and STS accessions that failed to produce any marketable size

\section{CONCLUSION}

Nine out of 21 accessions were potential as new clonal of $A$. muelleri because they had average corm production 5.91-99.88\% larger than the parent, i.e., BKB, BS, CF, CK, CR, DPG, DPP, SBM, and SHJ genotypes. Moreover, five accessions, i.e., CK, CR, DPG, DPP, and SBM gained $99.88 \%, 48.60 \%, 46.38 \%, 34.90 \%$ and $31.02 \%$ higher than its parent, respectively. Present study implies that improving production through clonal variation is prospective in $A$. muelleri. It needs further evaluation on genetic properties including heritability in order to understand the most valuable characters for selection in $A$. muelleri improvement.

\section{ACKNOWLEDGEMENTS}

We would like to thank Ministry of Research, Technology and Higher Education (Menristekdikti), The Republic of Indonesia for financial support by the Decentralized Strategic Applied Research Grant (PTUPT) for FY 2017-2018 to Dr Edi Santosa.

\section{REFERENCES}

Acquaah, G. 2012. Principle of Plant Genetics and Breeding. $2^{\text {nd }}$ edition. John Wiley \& Sons, USA.

Afifah, E., M.O. Nugrahani, Setiono. 2014. Prospect of ilesiles (Amorphophallus spp.) as an intercrop in hevea plantation. Warta Perkaretan 33:35-46.

Barcaccia, G., E. Albertini. 2013. Apomixis in plant reproduction: a novel perspective on an old dilemma. Plant Reproduction 26:159-179.

Budiman, E. Arisoesilaningsih. 2012. Predictive model of Amorphophallus muelleri growth in some agroforestry in East Java by multiple regression analysis. Biodiversitas 13:18-22. DOI: 10.13057/ biodiv/d130104.

Chinedu, N.E. 2017. Stability of tuber shape in Dioscorea rotundata variants. Int. J. Life. Sci. Scienti. Res. 3: 779-782. 
Dai, S., H. Corke, N.P. Shah. 2016. Utilization of konjac glucomannan as a fat replacer in low-fat and skimmed yogurt. J. Dairy Sci. 99:7063-7074. DOI: 10.3168/ jds.2016-11131.

Dani, T. 2008. Identification of Ploidy Level on Sibling of Triploid Iles-iles (Amorphophallus muelleri Blume) from Seed. Thesis. Faculty of Agriculture, Gajah Mada University. Yogyakarta, ID.

Dwiyono, K. 2014. The Process Improvement of Ilesiles Tuber (Amorphophallus muelleri Blume) for Glucomannan Agroindustry. Dissertation. Graduate School of Industrial Agriculture Technology. Bogor Agricultural University. Bogor. Http://repository.ipb. ac.id/jspui/bitstream/123456789/70064/1/2014ldw. pdf.

Hand, M.L., A.M. Koltunow. 2014. The genetic control of apomixis: Asexual seed formation. Genetics 197: 441-450.

Hananto, S., S. Pujiyanto, E. Kusdiyantini. 2015. Proximate content and binding ability of iles-iles flour (Amorphophallus oncophyllus) to aflatoxin as alternative binding material for feed. J. Biol. 4:53-65. (In Indonesian).

Haryani, K., Hargono. 2008. Processing of iles-iles (Amorphophallus sp.) to glukomannan as gelling agent for borax replacement. Momentum 4:38-41.

Islam, Md.T., R.U. Chowdhury, R. Afroz, S. Rahman, Md.M. Haque. 2011. Characterization and maintenance of yam (Dioscorea spp.) germplasm. Bangladesh J. Agril. Res. 36:605-621.

Kandemir, N., I. Saygili. 2015. Apomixis: new horizon in plant breeding. Turkish J. Agric. Forestry 39:1-7.

Keithley, J.K., B. Swanson, S.L. Mikolaitis, M. DeMeo, J.M. Zeller, L. Fogg, J. Adamji. 2013. Safety and efficacy of glucomannan for weight loss in overweight and moderately obese adults. J. Obes. 2013:610908. DOI: $10.1155 / 2013 / 610908$.

Mekkerdchoo, O., P. Holford, G. Srednicki, C. Prakitchaiwattana, C. Borompichaichartkul, S. Wattananon. 2011. Determination of relationship and genetic variation among Amorphophallus sp. from northern part of Thailand. Thai J. Agric. Sci. 44:129136.

Mulyadiana, A., Trikoesoemaningntyas, I.Z. Siregar. 2019. Evaluation of early growth performance of 41 clones of teak (Tectona grandis Linn. F) at four microsites in Purwakarta, Indonesia. J. For. Res. DOI: 10.1007/ s11676-019-00878-0.
Nikmah, I.A., R. Azrianingsih, D. Wahyudi. 2016. Genetic diversity of porang populations (Amorphophallus muelleri Blume) in Central Java and West Java based on $L E A F Y$ second intron marker. J. Trop. Life Sci. 6:23-27.

Poerba, Y.S., D. Martanti. 2008. Genetic variability of Amorphophallus muelleri Blume in Java based on random amplified polymorphic DNA. Biodiversitas 9:245-249.

[PPKKP] Pusat Penganekaragaman Konsumsi dan Keamanan Pangan, Badan Ketahanan Pangan Kementerian Pertanian. 2013. Iles-iles Cultivation. Http://www.pusat-pkkp.bkp.pertanian.go.id/berita357-budidaya- ilesiles. html. (In Indonesian).

Pranamulya, A.S., O. Syafruddin, W. Setiawan. 2013. Economic value of intercropping in community forest (Case study in community forest area Tembong Podol, Rambatan village, Ciniru, Kuningan District). Wanaraksa 7:1-9.

Rachmawati, E. 2008. Partnership between Perum Perhutani and Vanilla Farmers in an Effort to Improve the Farmers Income: A Case Study of CommunityBased Management of Forest Resources (CBFR) in the Sub-district of Padasari, District of Cimalaka, Regency of Sumedang. Master Thesis. Bogor Agricultural University. https://repository.ipb.ac.id/ jspui/bitstream/123456789/9160/2/2008era.pdf.

Rofik, K., R. Setiahadi, I.R. Puspitawati, M. Lukito. 2017. Production potency of porang (Amorphophallus muelleri Blume) in farmer group MPSDH Wono Lestari Padas village, Dagangan subdistrict, Madiun District. AGRI-TEK 17:53-65. http:// unmermadiun.ac.id/ejurnal/index.php/agritek/ article/download/187/364 (In Indonesian).

Rosidiani, E.P., E.L. Arumingtyas, R. Azrianingsih. 2013. Analysis of genetic variation of Amorphophallus muelleri Blume from several populations in East Java based on sequence intron trnL. Floribunda 4:129137.

Santosa, E., N. Sugiyama. 2007. Growth and production of Amorphophallus paeoniifolius Dennst. Nicolson from different corm weights. J. Agron. Indonesia 35:23-35.

Santosa, E., N. Sugiyama, S. Hikosaka, M. Nakata, H. M. H. Bintoro. 2004. Effect of planting depth on growth and yield of two Amorphophallus species cultivated in Indonesia. Japanese J. Trop. Agric. 48:240-245. 
Santosa, E., A. Kurniawati, M. Sari, A.P. Lontoh. 2016a. Agronomic manipulation on flowering of iles-iles (Amorphophallus muelleri Blume) to enhance seed production. J. Ilmu Pertanian Indonesia 21:133-139. DOI: $10.18343 /$ jipi.21.2.133.

Santosa, E., A.D. Susila, A.P. Lontoh, Y. Mine, N. Sugiyama. 2016b. NPK levels and application methods on productivity of Amorphophallus muelleri Blume in intercropping system. J. Jamu Indonesia 1:1-8.

Santosa, E., N. Sugiyama, A. Kurniawati, A. P. Lontoh, M. Sari, Krisantini. 2018. Variation in floral morphology of agamosporous Amorphophallus muelleri Blume of natural and gibberellin flowerings. J. Appl. Hort. 20:15-29.

Savidan, Y., J.G. Carman, T. Dresselhaus. 2001. The Flowering of Apomixis: From Mechanisms to Genetic Engineering. Mexico, D.E: CIMMYT, IRD, European Commission DC VI (FAIR).

Sedayu, A., M.C.M. Eurlings, B. Gravendeel, W.L.A. Hetterscheid. 2010. Morphological character evolution of Amorphophallus (Araceae) based on a combined phylogenetic analysis of $t r n \mathrm{~L}, r b c \mathrm{~L}$ and $L E A F Y$ second intron sequences. Bot. Studies 51: 473-490.

Sugiyama, N., E. Santosa. 2008. Edible Amorphophallus in Indonesia - Potential Corps in Agroforestry. Gadjah Mada University Press, Yogyakarta. ID.
Sumarwoto, W. Widodo. 2008. Growth and yield of elephant foot yam (Amorphophallus muelleri Blume) first growing period of different $\mathrm{N}$ and $\mathrm{K}$. Agrivita 30: $67-74$.

Supriadi, H., D. Pranowo. 2015. Prospects of agroforestry development based on coffee in Indonesia. Perspektif 14:135-150.

Syukur, M., S. Sujiprihati, R. Yunianti. 2015. Crop Breeding Technique. Penebar Swadaya, Jakarta, ID (In Indonesian).

Widjanarko, S.B., T.S. Suwasito. 2014. The effect of grinding duration using ball mill on the yield and hydration capability of konjac flour (Amorphophallus muelleri Blume). J. Pangan Agroindustri 2:79-85.

Yang, D., Y. Yuan, L. Wang, X. Wang, R. Mu, J. Pang, J. Xiao, Y. Zheng. 2017. A review on konjac glucomannan gels: microstructure and application. Int. J. Mol. Sci. 18:2250. DOI: 10.3390/ijms18112250.

Zhang, D., Q. Wang, S. George. 2010. Mechanism of staggered multiple seedling production from $A$. bulbifer and $A$. muelleri and its implication to cultivation in Southeast Asia. Trop. Agric. Dev. 54:84-90.

Zhao, J., D. Zhang, G. Srzednicki, S. Kanlayanarat, C. Borompichaichartkul. 2010. The morphological and growth characteristics of Amorphophallus muelleri Blume - a commercially important konjac species. Acta Hortic. 875:501-508. 